\title{
UNITED NATIONS' SUSTAINABLE DEVELOPMENT GOALS REVIEW - DUAL ANALYSIS OF ROMANIA AND DENMARK
}

\author{
Vlad Constantin Turcea ${ }^{1}$ \\ *Corresponding author E-mail: vladturcea@gmail.com
}

\begin{abstract}
A R T I C L E I N F O
A B S T R A C T

Review Article

Received: 24 April 2020

Accepted: 25 August 2020

The present paper aims to highlight the discrepancies

doi:10.5937/ekoPolj2004309T

UDC 502.131.1(1-544)(498)(489) between two countries of the European Union, Romania and Denmark, in the perspective of the Sustainable Development Goals. As Denmark is seen as a primer European and Global nation in achieving the United Nations' targets, Romania can use this example as a guideline on how to act and to obtain the most notable

Keywords:

Romania, Denmark, SDG, investment

JEL: $Q 01$ results. The article proposes some key principles that Romanians could follow in order to successfully fulfill the 2030 Action Plan having, as an example, the strategies and indicators reached by Denmark. The current work paper is structured as a review of the two reports that voluntarily summarize the situation of the Sustainable Development Goals in each state, followed by a statistical analysis of investment behavior and concluded with an analysis of the most notable differences between the states based on the dataset published by Eurostat.
\end{abstract}

(C) 2020 EA. All rights reserved.

\section{Introduction}

The concept of sustainability recalls human efforts in building a future that is comprehensive and optimistic for the planet and its people.

Sustainability came to light as a peripheral of business ethics, as an answer to general displeasure of the virtually permanent damage caused by a continuous focus on immediate profits.

In 2000, 189 countries agreed on a plan for the new millennia, they planned to end extreme poverty in all its forms, together with other ambitious and necessary visions and therefore, a list of several goals was created, Millennium Development Goals, counting in total 8 goals that aspired to eradicate extreme hunger, to improve maternal health, to achieve universal primary education, to combat diseases, to promote gender equality and to empower women, to ensure environmental stability, to reduce child mortality and to develop global partnership for improvement (U.N., 2015). These goals

1 Vlad Constantin Turcea, PhD. student, Bucharest University of Economic Studies, 6 Piața Romană, Bucharest, Phone: +40741012913, E-mail: vladturcea@gmail.com, ORCID ID (https://orcid.org/0000-0002-3037-6063)

http://ea.bg.ac.rs 
were to be reached in 15 years. With the help of several global organizations, notable progresses have been registered but efforts still had to be made, so that in September 2015, a new set of goals had been agreed, to help finish the work that was started in year 2000, the new goals were called the Sustainable Development Goals (SDG-s) that formulate the plan up to the year 2030 (U.N., 2020). In today's technological society, it is known more on how to balance the three pillars of sustainable development, consisting in social progress, economic growth and environmental protection.

Year 2015 stands as a beacon of hope in our way to achieve a prosperous and sustainable world where everyone can have a productive, vibrant and peaceful life in a healthy environment through the introduction of the 17 Sustainable Development Goals. All the new Goals are unparalleled since they recall global input, regardless of economic, social or political status. The goals come to encourage expansion and growth without harming the planet, this is why the leaders identified the need of a handin-hand strategy for the quest of ending poverty with the ability of building economic prosperity addressing the classical social needs of health, social responsibility, labor and education whilst undertaking the most urgent need of our world (climate change and environment protection).

Since the inception of the 2030 United Nations'(UN)Agenda for Sustainable Development, mankind has decided to further focus on quintessential aspects for a sustainable world. In the foreseen future of the next fifteen years, with the seventeen goals, UN's Agenda will assemble the world's efforts to put an end to poverty and inequalities and to deal with climate change making certain that not a single community is marooned.

As this paper will make a comparison of the Danish and Romanian strategies in accordance with the Sustainable Development Goals of the United Nations' Agenda 2030, it can be identified that Denmark is a primer nation according to the SDG Index Report (Sachs, Shmidt-Traub, Kroll, Lafortune, \& Fuller, 2019). What does Romania misses? Where is Denmark exceeding in? What Romanians must do to catch up or at least follow the Danes? Those are the questions that this article aims to give answers to.

According to the Sustainable Development Report (Sachs, Shmidt-Traub, Kroll, Lafortune, \& Fuller, 2019), Denmark together with all the Nordic countries top up the SDG Index. Challenges have been faced even by Denmark implementation process of the SDG-s. Not a single country is progressing on the path of achieving all the 17 goals. Important gaps on the following SDG-s have been registered even for Denmark: SDG 12 (Responsible Consumption and Production); SDG 13 (Climate Action); SDG 14 (Life Below Water) and SDG 15 (Life on Land).

On the one hand, Romania's Voluntary National Review would be revised (Ministry of Environment, 2019), a key document for this article, that was completed under the guidance of the Ministry of Environment with its Inter-Ministerial Committee assisted by other governmental institutions and representatives of civil society and academic area. SDG-s management is in the attributes of the Ministry of Foreign Affairs as main coordinator and the respective ministry for each goal; and Romania's mission to 
enclose the Agenda in nation's core strategy represents an inter-institutional cooperation effort. In 2017, local governmental bodies with their Sub-Committee for Sustainable Development assumed the responsibility of the 2030 Agenda's implementation at a national level. The National Voluntary Review is mainly focusing on 6 SDG-s (SDG 6 - Clean Water and Sanitation; SDG 7 - Affordable and Clean Energy; SDG 11 - Sustainable Cities and Communities; SGD 12 - Responsible Consumption and Production; SDG 15 - Life on Land; SDG 17 - Partnerships for the Goals). The document has as a foreword the chapter "Leave no one behind" that summarizes the recent GDP growth for Romania 4.8\% in 2016, 6.9\% in 2017 and 4\% in 2018 (World Bank, 2020); the Review also tackles the demographic decline of current times (a yearly decrease of population of an average of $0.56 \%$ over years from 2007 through 2018 and a decrease of $2.5 \%$ in 2018 compared to 2013). This classical structure of the report based on the targets set up by the UN is a poor method of presenting the strengths of a nation, that is why Denmark's model has been chosen as to complete the comparative analysis.

On the other hand, Denmark's Review (Ministry of Finance, 2019), for the initial part presents a national commitment defining the necessity of SDG-s incorporation into the national legislation. The SDG-s act as protagonists on the domestic landscape and all the highlighted points in this report, are a guidance for global development moving forward to year 2030, as Denmark being a primer country in the 2019 SDG Index Report, on account of its governmental delivery. In Denmark, the Ministry responsible for the SDG-s coordination is the Foreign Affairs' and the Finance one. The governmental plan to turn SDG-s into tangible and actionable items is entitled "The Action Plan" and is centered around 5 main topics, the same "P"-s as the ones in the Agenda 2030. For each individual "P" of Denmark, excluding "Partnership", the government formulated several targets (in total 37 of them) that come to merge some of the SDG-s, each of the target above has multiple national indicators which can be quantifiable and measurable, highlighting the fact that the SDG-s formulated by the UN do not solely represent a strategy, proof that each nation needs to adapt and translate the universal guide to its needs and specifications.

\section{Materials and methods}

The following lines represent the review of the reports presented as a dual analysis of the SDG Voluntary Reviews, shown in Table A1, as a presentation enforced by indices that are not linked to the Eurostat's SDG-s dedicated analyses, showing the following: Denmark's status according to what has been published in its National Voluntary Review (first column); in the next column it is presented the Romania's status on the respective SDG in the similar document; the last column focuses on what Romania could do in order to progress in achieving the respective SGD.

The SDG-s represent a multitude of assortments that investors can opt to use in order to flavor this delightful journey towards a better world. Looking into the historical data and past decisions, the work of all of SDG-s' stakeholders is to lead to an improved 
understanding on defining an idealistic investment strategy. The SDG-s also represent 17 guidelines for the investors to take into consideration, while the evolution of the progress, at this point of time, can be properly recorded grace to the SDG reporting framework (PricewaterhouseCoopers, 2017).

The present paper aims to emphasize the importance of SDG improvement; a regression model will be used in analyzing both Danish and Romanian progress in this journey, by looking at the GDP (Gross Domestic Product) evolution, as suggested in the specialized literature (Cruceanu, Anghel, \& Diaconu, 2016; Glass \& Newig, 2019). Subsequently, a separate analysis on each SDG will be conducted to obtain additional detailed results.

The main data source for this study is Eurostat; in order to perform the comparison between the two countries, all indicators were converted in euro/capita. The correlation of the indices to the respective SDG can be seen in Table A2. Next, both models will be addressed, and the datasets will be analyzed with the EViews 11 Student Version software.

The dependent variable is represented by the GDP of the respective country while the independent variables are as follows, for each individual state: Business Research Expenditure, Governmental Environmental Expenditure, Governmental Education Expenditure, Governmental Research and Development Expenditure, Governmental Agricultural Research and Development Expenditure, Governmental Health Expenditure, Governmental Social Protection Expenditure and Total Investment, the selected time interval being from 2000 to 2018.

The results highlight the importance of sound investment strategy that thrives economic boom together with SDG-s implementation improvement using econometric modeling. Additional statistical methods, based on official data, will be used to complete the policy and paper reviews, as a base for the final conclusions.

In the datasets for both countries, shown in Table A3 \& A4, can be observed that Denmark recorded an ascending trend over the years for the GDP index but at a slower pace, situation matching the general SDG-s improvement, situation similar for Romania. For the econometric model to have validity, the datasets will be subjected to multiple tests as described in the following section.

\section{Results \& Discussions}

\section{Descriptive statistics and econometric models}

The first series of tests, presenting the descriptive statistics and the normalization distribution of the series - as shown in Table 1, relate that all the indices present a normalized structure, the distribution recorded normal values for all indices, Kurtosis recorded values lesser than 3 , representing a platykurtic distribution; assuming a normal distribution for the indicator, the following hypotheses have been formulated $\mathrm{H} 0$ : representing a normal distribution with the respective probability higher than 5\%; H1: representing an abnormal distribution for the opposite probability; in this case, looking at the table, $\mathrm{H} 0$ is confirmed for all of the indices. 
Table 1. Normalization of the database - Denmark \& Romania

\begin{tabular}{|c|c|c|c|c|c|c|c|c|}
\hline $\begin{array}{c}\text { Denmark/ } \\
\text { Romania }\end{array}$ & Mean & Median & Max & Min & $\begin{array}{l}\text { Std. } \\
\text { Dev. }\end{array}$ & Skewness & Kurtosis & $\begin{array}{l}\text { Prob. } \\
>5 \% ? \\
(\mathrm{Y} / \mathrm{N})\end{array}$ \\
\hline GDP DK & 44,635 & 44,400 & 48,260 & 42,190 & 1,768 & 0 & 2 & $\mathrm{Y}$ \\
\hline GDP RO & 6,127 & 6,350 & 8,740 & 4,010 & 1,404 & 0 & 2 & $\mathrm{Y}$ \\
\hline $\begin{array}{c}\text { Business } \\
\text { Research Exp. } \\
\text { DK } \\
\end{array}$ & 816 & 835 & 941 & 616 & 98 & (0) & 2 & Y \\
\hline $\begin{array}{c}\text { Business } \\
\text { Research Exp. } \\
\text { RO } \\
\end{array}$ & 13 & 11 & 26 & 8 & 5 & 2 & 5 & Y \\
\hline $\begin{array}{c}\text { Gov. } \\
\text { Environment } \\
\text { Exp. DK } \\
\end{array}$ & 220 & 222 & 297 & 173 & 39 & 0 & 2 & Y \\
\hline $\begin{array}{c}\text { Gov. } \\
\text { Environment } \\
\text { Exp. RO } \\
\end{array}$ & 36 & 39 & 73 & 5 & 22 & 0 & 2 & $\mathrm{Y}$ \\
\hline $\begin{array}{c}\text { Gov. Education } \\
\text { Exp. DK } \\
\end{array}$ & 3,569 & 3,555 & 3,795 & 3,197 & 157 & (0) & 3 & $\mathrm{Y}$ \\
\hline $\begin{array}{c}\text { Gov. Education } \\
\text { Exp. RO } \\
\end{array}$ & 210 & 216 & 289 & 115 & 52 & 9 & 2 & $\mathrm{Y}$ \\
\hline $\begin{array}{c}\text { Gov. R\&D Exp. } \\
\text { DK }\end{array}$ & 51 & 37 & 118 & 25 & 29 & 1 & 3 & Y \\
\hline $\begin{array}{c}\text { Gov. R\&D Exp. } \\
\text { RO } \\
\end{array}$ & 10 & 11 & 16 & 3 & 4 & (1) & 2 & Y \\
\hline $\begin{array}{c}\text { Gov. } \\
\text { Agricultural } \\
\text { R\&D Support } \\
\text { DK } \\
\end{array}$ & 82 & 79 & 99 & 69 & 9 & 0 & 2 & Y \\
\hline $\begin{array}{c}\text { Gov. } \\
\text { Agricultural } \\
\text { R\&D Support } \\
\text { RO } \\
\end{array}$ & 1 & 1 & 3 & 0 & 1 & 1 & 3 & Y \\
\hline $\begin{array}{c}\text { Gov. Health } \\
\text { Exp. DK } \\
\end{array}$ & 3,541 & 3,716 & 4,006 & 2,827 & 397 & (1) & 2 & $\mathrm{Y}$ \\
\hline $\begin{array}{c}\text { Gov. Health } \\
\text { Exp. RO }\end{array}$ & 242 & 247 & 411 & 153 & 72 & 1 & 3 & $\mathrm{Y}$ \\
\hline $\begin{array}{c}\text { Gov. Social } \\
\text { Protection Exp. } \\
\text { DK } \\
\end{array}$ & 10,333 & 10,502 & 10,927 & 9,408 & 484 & (0) & 2 & Y \\
\hline \begin{tabular}{|c|} 
Gov. Social \\
Protection Exp. \\
RO \\
\end{tabular} & 696 & 777 & 1,014 & 417 & 201 & $(0)$ & 2 & Y \\
\hline $\begin{array}{c}\text { Total } \\
\text { investment DK } \\
\end{array}$ & 9,247 & 9,029 & 10,864 & 7,939 & 918 & 1 & 2 & Y \\
\hline $\begin{array}{c}\text { Total } \\
\text { investment RO }\end{array}$ & 1,548 & 1,675 & 2,510 & 767 & 462 & (0) & 3 & $\mathrm{Y}$ \\
\hline
\end{tabular}

Source: EVIEWS 11 SV - Author's calculation 
In order to test the individual stationarity, the datasets were assessed to evaluate the unit root existence and it was calculated that data was not stationary and following the statistical process, the first difference was needed to be implemented causing all the variables to modify, the descriptive statistics being tested again. The process of differentiating represents the reduction of the database with one year due to the variance across the years and consists in the stabilization of the series removing the seasonality and trend. Summarized, in Table 2, it can be observed what variables remained normalized after the respective operation and the following hypotheses have been considered H0: where data is stationary and does not have a unit root for the probability lesser than $5 \%$ and the absolute value of t-Stat being above the critical value in the 1, 5 and $10 \%$ moments and H1: where data is not stationary and has a unit root for the opposite probability and critical value, including in the test's equation the trend, intercept, none or both at the same time as observable in the table. The probability presented values below 5\% for all variables with two exceptions for Romania and considering that the t-statistical was above the critical value, $\mathrm{H} 0$ could be confirmed. The probability for the group testing is $0 \%$ for both Levin, Lin \& Chu and ADF \& PP - Fisher Chi-square tests, indicating the stationarity of the data and the absence of the unit reconfirming that the variables can continue the statistical process.

Table 2. Normalization re-testing \& Stationarity testing - Denmark \& Romania

\begin{tabular}{|c|c|c|c|c|c|c|}
\hline & & \multicolumn{5}{|c|}{$\begin{array}{c}\text { Unit Root Test | Augmented Dickey-Fuller } \\
\end{array}$} \\
\hline $\begin{array}{c}\text { Denmark / } \\
\text { Romania }\end{array}$ & Normalized? & $\begin{array}{c}\text { Intercept / } \\
\text { Trend } \\
\end{array}$ & $\begin{array}{c}\mathrm{t}-\text { Stat }> \\
\text { critical } 1 \% ?\end{array}$ & $\begin{array}{c}\text { t-Stat }> \\
\text { critical } 5 \% ?\end{array}$ & $\begin{array}{c}\mathrm{t}-\mathrm{Stat}>\text { critical } \\
10 \% ?\end{array}$ & Prob. \\
\hline GDP DK & No & $\mathrm{N} / \mathrm{A}$ & Yes & Yes & Yes & $1 \%$ \\
\hline GDP RO & Yes & Intercept & No & Yes & Yes & $8 \%$ \\
\hline $\begin{array}{c}\text { Business } \\
\text { Research Exp. } \\
\text { DK }\end{array}$ & Yes & N/A & Yes & Yes & Yes & $1 \%$ \\
\hline $\begin{array}{c}\text { Business } \\
\text { Research Exp. } \\
\text { RO } \\
\end{array}$ & Yes & N/A & No & Yes & Yes & $2 \%$ \\
\hline $\begin{array}{c}\text { Gov. } \\
\text { Environment } \\
\text { Exp. DK }\end{array}$ & Yes & $\mathrm{N} / \mathrm{A}$ & Yes & Yes & Yes & $<1 \%$ \\
\hline $\begin{array}{c}\text { Gov. } \\
\text { Environment } \\
\text { Exp. RO } \\
\end{array}$ & Yes & N/A & Yes & Yes & Yes & $<1 \%$ \\
\hline $\begin{array}{c}\text { Gov. } \\
\text { Education } \\
\text { Exp. DK } \\
\end{array}$ & Yes & N/A & Yes & Yes & Yes & $<1 \%$ \\
\hline $\begin{array}{c}\text { Gov. } \\
\text { Education } \\
\text { Exp. RO } \\
\end{array}$ & Yes & N/A & No & Yes & Yes & $3 \%$ \\
\hline $\begin{array}{c}\text { Gov. R\&D } \\
\text { Exp. DK }\end{array}$ & No & N/A & Yes & Yes & Yes & $<1 \%$ \\
\hline $\begin{array}{l}\text { Gov. R\&D } \\
\text { Exp. RO }\end{array}$ & Yes & N/A & Yes & Yes & Yes & $<1 \%$ \\
\hline
\end{tabular}




\begin{tabular}{|c|c|c|c|c|c|c|}
\hline \multirow[b]{2}{*}{$\begin{array}{l}\text { Denmark / } \\
\text { Romania }\end{array}$} & \multirow[b]{2}{*}{ Normalized? } & \multicolumn{5}{|c|}{ Unit Root Test | Augmented Dickey-Fuller } \\
\hline & & $\begin{array}{l}\text { Intercept / } \\
\text { Trend }\end{array}$ & $\begin{array}{c}\mathrm{t}-\text { Stat }> \\
\text { critical } 1 \% ?\end{array}$ & $\begin{array}{c}\text { t-Stat }> \\
\text { critical 5\%? }\end{array}$ & $\begin{array}{c}\text { t-Stat }>\text { critical } \\
10 \% ?\end{array}$ & Prob. \\
\hline $\begin{array}{c}\text { Gov. } \\
\text { Agricultural } \\
\text { R\&D Support } \\
\text { DK }\end{array}$ & Yes & $\mathrm{N} / \mathrm{A}$ & Yes & Yes & Yes & $<1 \%$ \\
\hline $\begin{array}{c}\text { Gov. } \\
\text { Agricultural } \\
\text { R\&D Support } \\
\text { RO }\end{array}$ & Yes & N/A & Yes & Yes & Yes & $<1 \%$ \\
\hline $\begin{array}{c}\text { Gov. Health } \\
\text { Exp. DK }\end{array}$ & Yes & Intercept & Yes & Yes & Yes & $<1 \%$ \\
\hline $\begin{array}{c}\text { Gov. Health } \\
\text { Exp. RO }\end{array}$ & Yes & $\mathrm{N} / \mathrm{A}$ & No & No & No & $13 \%$ \\
\hline $\begin{array}{c}\text { Gov. Social } \\
\text { Protection } \\
\text { Exp. DK }\end{array}$ & No & $\mathrm{N} / \mathrm{A}$ & No & Yes & Yes & $1 \%$ \\
\hline $\begin{array}{c}\text { Gov. Social } \\
\text { Protection } \\
\text { Exp. RO }\end{array}$ & Yes & $\mathrm{N} / \mathrm{A}$ & No & No & No & $10 \%$ \\
\hline $\begin{array}{c}\text { Total } \\
\text { investment DK }\end{array}$ & No & $\mathrm{N} / \mathrm{A}$ & No & Yes & Yes & $3 \%$ \\
\hline $\begin{array}{c}\text { Total } \\
\text { investment RO }\end{array}$ & No & $\mathrm{N} / \mathrm{A}$ & Yes & Yes & Yes & $<1 \%$ \\
\hline
\end{tabular}

Source: EVIEWS 11 SV - Author's calculation

Using the correlogram analysis, shown in Table 3, the variables fit between the autocorrelation dotted lines, meaning that the seasonality of the series was not registered validating that the variables are statistically representative.

Table 3. Correlogram - Denmark \& Romania

\section{Denmark}

\section{Romania}

\begin{tabular}{|c|c|c|c|c|c|c|c|c|c|}
\hline \multicolumn{6}{|c|}{$\begin{array}{l}\text { Date: } 03 / 30 / 20 \text { Time: } 13: 30 \\
\text { Sample (adjusted): } 20012018 \\
\text { Included observations: } 18 \text { after adjustments } \\
\text { Autocorrelation } \quad \text { Partial Correlation }\end{array}$} & $A C$ & PAC & Q-Stat & Prob \\
\hline 1 & $\square$ & 1 & 1 & 1 & 1 & 0.262 & 0.262 & 1.4554 & 0.228 \\
\hline 1 & & 1 & & 1 & 2 & -0.018 & -0.093 & 1.4627 & 0.481 \\
\hline $1 \sqsubset$ & ت & 1 & $1 \square$ & 1 & 3 & -0.285 & -0.277 & 3.4168 & 0.332 \\
\hline 1 & & 1 & 1 & 1 & 4 & -0.139 & 0.009 & 3.9144 & 0.418 \\
\hline 1 & ㅁ & 1 & 무 & 1 & 5 & -0.151 & -0.148 & 4.5499 & 0.473 \\
\hline 1 & l & 1 & c & 1 & 6 & -0.037 & -0.055 & 4.5920 & 0.597 \\
\hline 1 & 다요 & 1 & $1 \square$ & 1 & 7 & -0.141 & -0.188 & 5.2452 & 0.630 \\
\hline 1 & C & 1 & С & 1 & 8 & -0.099 & -0.130 & 5.5986 & 0.692 \\
\hline 1 & 도 & 1 & 무 & 1 & 9 & -0.108 & -0.138 & 6.0637 & 0.734 \\
\hline 1 & 7 & 1 & 1 & 1 & 10 & 0.070 & -0.015 & 6.2866 & 0.791 \\
\hline 1 & 2 & 1 & 1 & 1 & 11 & 0.083 & -0.059 & 6.6404 & 0.827 \\
\hline 1 & 5 & 1 & 1 & 1 & 12 & 0.099 & -0.060 & 7.2298 & 0.842 \\
\hline
\end{tabular}

\begin{tabular}{l}
$\begin{array}{l}\text { Date: } 03 / 12 / 20 \text { Time: } 17: 46 \\
\text { Sample (adjusted): } 20012018 \\
\text { Included observations: } 18 \text { after adjustments } \\
\text { Autocorrelation }\end{array}$ Partial Correlation \\
\hline \hline
\end{tabular}

Source: EVIEWS 11 SV - Author's calculation 
Covariance analysis of the GDP indicator can be observed in Table 4, where the probability registered a value above 5\% for most of the variables but for the following differentiated indices for Denmark: Gov. Social Protection Exp. (Social) and Total investment (Inv) displaying a strong relationship between the GDP of Denmark and the last two indices, while the others show a percentage of the probability above $10 \%$ representing their independence from the GDP indicator. In the Romanian case, the probability registered a value above 5\% for most of the variables except Gov. Education Exp. (Educ), Gov. R\&D Exp. (GovR\&D) and Total investment (Inv), the low percentage of the probability displays a strong relationship between the GDP of Romania and the respective indices, while Gov. Environment Exp. (Env) and Gov. Agricultural R\&D Support (AgriR\&D) show a percentage of the probability above $40 \%$ representing independence from the GDP indicator.

Table 4. Covariance analysis - Denmark \& Romania

\begin{tabular}{|c|c|c|c|c|c|c|c|c|c|}
\hline $\begin{array}{c}\text { Denmark/ } \\
\text { Romania }\end{array}$ & GDP & Env & Educ & Buss & AgriR\&D & GovR\&D & Health & Social & Inv \\
\hline DK GDP & NA & $12 \%$ & $84 \%$ & $32 \%$ & $89 \%$ & $36 \%$ & $12 \%$ & $<1 \%$ & $<1 \%$ \\
\hline RO GDP & NA & $75 \%$ & $<1 \%$ & $32 \%$ & $46 \%$ & $1 \%$ & $5 \%$ & $16 \%$ & $<1 \%$ \\
\hline
\end{tabular}

Source: EVIEWS $11 \mathrm{SV}$ - Author's calculation

The linear model for Denmark represents an equation, using the least squares method where the probability for the F-statistic test registered a value of 0.00217 which is below the 0.05 statistically accepted threshold and it correlates with the great impact of the exogenous variables over the endogenous ones. The R-squared value of the model is 0.8822 representing an increased capacity of the independent variables to explain the GDP of Denmark. The equation can be noticed at Equation 1 and the coefficients can be noticed in Table 5 for both countries showing what is required in order to have a 1 differenced euro/capita increase in the GDP of Denmark. For Romania, the probability for the F-statistic test registered a value of 0.00206 which is below 0.05 reconfirming the great impact of the exogenous variables over the endogenously one. The R-squared value of the model is 0.8837 representing an increased capacity of the independent variables to explain the GDP. In the same table can be observed what is required in order to have a 1 differenced euro/capita increase in the GDP of Romania.

Table 5. Coefficients of the Danish and Romanian model

\begin{tabular}{|c|r|r|}
\hline Index & Coefficients - Denmark & Coefficients - Romania \\
\hline GDP & N/A & N/A \\
\hline Business Research Exp. & $(4.7)$ & 12.7 \\
\hline Gov. Environment Exp. & 0.2 & $(5.2)$ \\
\hline Gov. Education Exp. & 0.4 & 4.2 \\
\hline Gov. R\&D Exp. & $(15.3)$ & 45.2 \\
\hline Gov. Agricultural R\&D Support & 12.9 & $(77.2)$ \\
\hline Gov. Health Exp. & $(2.2)$ & 4.3 \\
\hline Gov. Social Protection Exp. & 0.5 & 0.9 \\
\hline Total investment & 1.4 & 0.3 \\
\hline Constant & 327.5 & 103.2 \\
\hline
\end{tabular}

Source: EVIEWS 11 SV - Author's calculation 
Equation 1. GDP model equation for Denmark and Romania

$$
G D P=C 1 \times \text { Bus.Res.Exp }+C 2 \times \text { Gov.Env.Exp. }+ \text { C3 } 3 \text { Gov.Educ.Exp. }+
$$

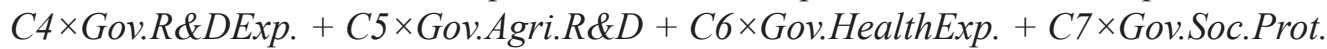

$$
\text { Exp. }+ \text { C8×TotalInv. }+C
$$

Next, the database will be investigated to get the homoscedastic diagnosis using White's heteroskedasticity test; the probability for this test records a value above the $5 \%$ statistically accepted margin for all of the indices, Denmark recorded for $F(8,9) 20.99 \%$ and for Chi-Square $20.36 \%$. Another test that further analyses the residual correlation of the database is the LM Breusch-Godfrey that registered for the current dataset a statistically probability of $99.8 \%$ that strongly confirms the validity of the model. In Romanian's case, the probability for $\mathrm{F}(8,9)$ is $81.93 \%$ and Chi-Square is $68.69 \%$. The residual correlation of the database verified with LM Breusch-Godfrey test, registered for Romania, a value of $96 \%$ confirming once again the validity of the model.

With all the multiple tests presented above it can be confirmed that for both Denmark and Romania, the multiple sector investment influence the GDP of the country and represents an accurate indicator for the socioeconomic level. The strong existing correlation further indicates the need of public and private investment to increase the general SDG-s improvement.

\section{$\underline{\text { Sustainable Development Goals - a comparative analysis }}$}

How is the EU answering to the SDG-s in general? The European institutions have assessed that sustainable development is a core objective in the general policy, aspect fastened in the European Treaties and highlighted in key projects, policies and frameworks. The Agenda with its 17 Goals is the culmination of global efforts to achieve sustainable development.

Eurostat, in this case, is the governmental body in charge to regularly oversee improvement of the SDG-s in the EU and for this specific aspiration, the EU bodies created a set of a indicators to closely monitor the EU Member States progress.

\section{GOAL 1: No Poverty}

The first subject touched by the SDG guideline is the poverty and the aspiration of ending it in all its forms, all over the planet. The data shown in the previous part of the paper suggests how unacceptable it is from an EU Member State as Romania to have such high discrepancies, both when compared to the primer position and to the average of the Member States (as it could be observed in the following analyses). Even though the decreasing trend is a sign of improvement throughout all the indices, local government needs to focus its efforts into improving the life quality of Romanians. The disparity is caused mainly because of the unbalanced rural life where, as shown earlier, not even the sewerage and fresh water supply reach the entirety of the population. The essence of this SDG should not only be identified with the economic situation, that was shown to be precarious, but should also highlight the conditions and solutions for poverty diminishment. 


\section{GOAL 2: Zero Hunger}

The situation presented in Figure 1 where the agricultural research field can reveal the importance of the research, can be said that Romania is not offering enough credit to research in any field as the country is having a real agricultural potential that could be fully achieved with a proper funding in this area. The most important year for Romania where the largest funding recorded peak values was 2010, with almost EUR 60 million while Denmark registered values above this maximum of Romania throughout the whole period, with the largest value in 2006 EUR 93.89 million. The most alarming fact is that the numbers are going down, opposing to the ascending trend of both EU average and Denmark.

Figure 1. Government support to agricultural research and development (SDG 2)

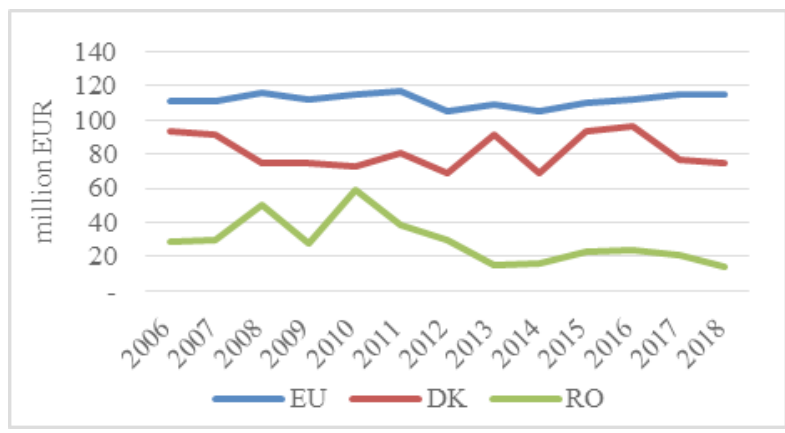

Source: Eurostat

Organic farming as presented in Figure 2 should represent a priority for Romania, as it matches the developing profile of the country's agriculture and the small average farm area, Romania recorded a descending trend over the years as opposed to the ascending trend in both EU and Denmark. Aspects, if properly advised, could increase the percentage of organic farms in this traditionally agricultural oriented member state of Romania, and could provide better opportunities through higher added value crops. The increasing trend of the EU average shows a growing interest for organic farming across Europe, with huge potential for countries like Romania to obtain increasing support.

Figure 2. Area under organic farming (SDG2)

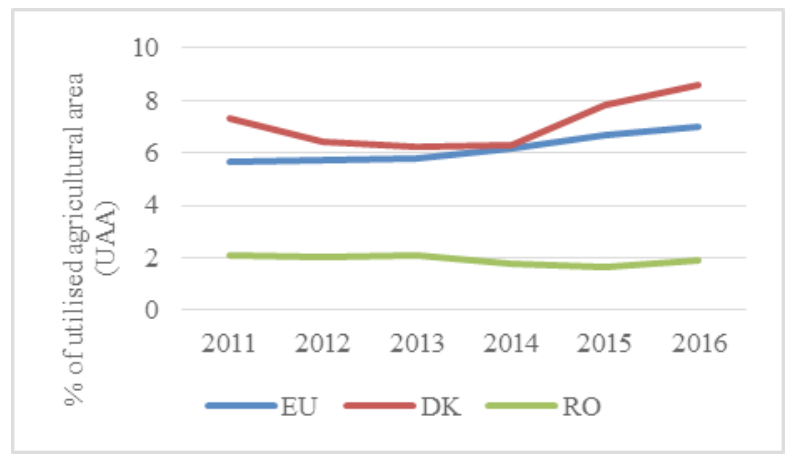

Source: Eurostat 
The next objective is to confine the hunger, to supply the population with enough food that fits the nutritional needs of each individual and to do so in a sustainable way. Even though Romania is known for the numerous small farmers, it is not a focus point in the Voluntary National Review as Denmark is doing for its small-scale farmers. Methods to encourage the cooperation between farmers in order to increase the agricultural output, together with smart investment, could improve the agricultural situation in Romania. It is a shame that agriculture is not a top research topic, but the immense potential of Romanian agriculture, should not be altered by other technological industrial niches and should coexist in a prosperous economy. Even though Romania, together with all the EU Member States, don't focus around national hunger, they are focusing on achieving the food security and what is foreseen to happen in the future, situation that might cause some large disturbances, due to the negligence over the nutritional security, especially in Romania where not enough lobby is made, and that the national food security could be in danger if the agriculture is not sustainable treated through clever crop management.

\section{GOAL 3: Good Health and Well-being}

The death rate index alone, as observed in Figure 3, can't reveal the true situation of Romania, but it can highlight the fact that the health-care system does not benefit at its maximum of how it should be when compared to both EU average and Denmark. The most important thing is that even for Romania it can be observed a decrease in the trend over the last 10 years. The variance for Romania over the years is around negative $20 \%$ while the improvement for Denmark reaches $29 \%$, this meaning that in absolute values, Denmark recorded a more significant decrease over the years.

Figure 3. Death rate due to chronic diseases (SDG3)

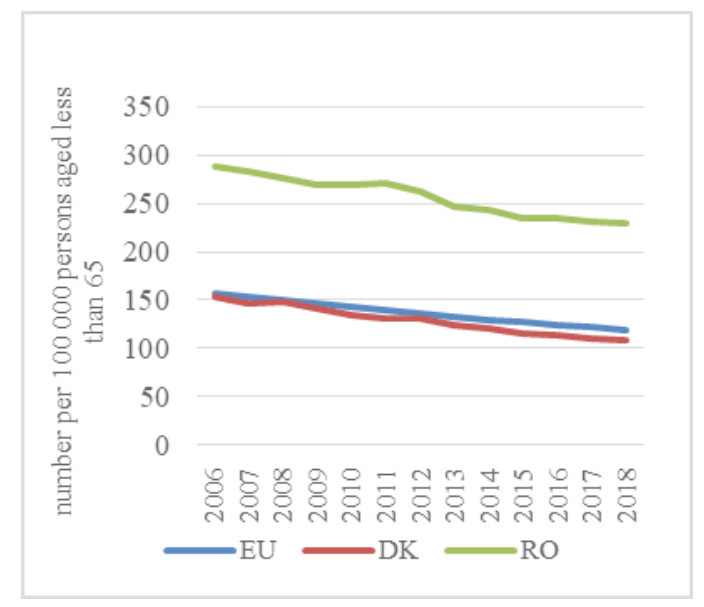

Source: Eurostat

The focus on ensuring a healthy life and promote the comfort for all ages should be attractive for each nation and additionally, each state should adapt this SDG on its specificities, an interesting aspect of this SDG is the fact that Romania's National 
Review has a more complex analysis of the health situation than what is presented in the Eurostat database, meaning that the disease-tracking is of high importance. Denmark's health situation looks a little better, but it is an absolute must to point out the dreadful state of public hospitals and the insufficient treatment points in Romania.

\section{GOAL 4: Quality Education}

Figure 4 is highlighting that in the last 3 years Romania has registered a decrease of early leavers from education, whereas Denmark recorded a slight increase and therefore, Romanian authorities should make a real effort into further decreasing the numbers to meet the European average. Romania recorded the lowest percentage of early leavers from training and education in 2008 with $15.9 \%$ while Denmark recorded its lowest in 2016 with 7.2\%. Denmark is a leading example and both Romania and the EU Member States should follow the Danish model in education where both investment and research are key objectives for the general wellbeing.

Figure 4. Early leavers from education and training (SDG4)

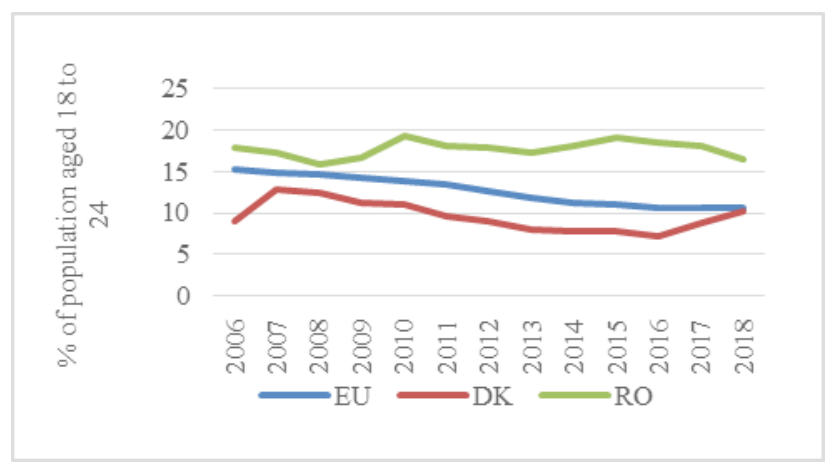

Source: Eurostat

According to what has been analyzed from both the National Review and the Eurostat database, Romanian efforts are not significant when compared to Denmark, where a greater GDP percentage is allocated for education and children are taught with top end technologies and up to date information. Meanwhile, Denmark succeeded in defining a minimum of learning that will assure each child's success in the current labor market. The Eurostat indices, unfortunately, place Romania lower than both Denmark and the EU average, a worrying trend that should be immediately reversed.

\section{GOAL 5: Gender Equality}

The situation presented in Figure 5, is a real problem in Romania due to the large percentage of the population that is not willing to either work or train. It is a terrifying situation knowing that for all variables the situation got worse over the years, of course Denmark registered lesser young people unemployed or involved in education, but even in this case, an ascending trend can be noticed over the years. This situation should be changed with a proper organizational movement that demands the unemployed to get trained and then to automatically be inserted in the labor market. 
Figure 5. Young people neither in employment nor in education and training (SDG5)

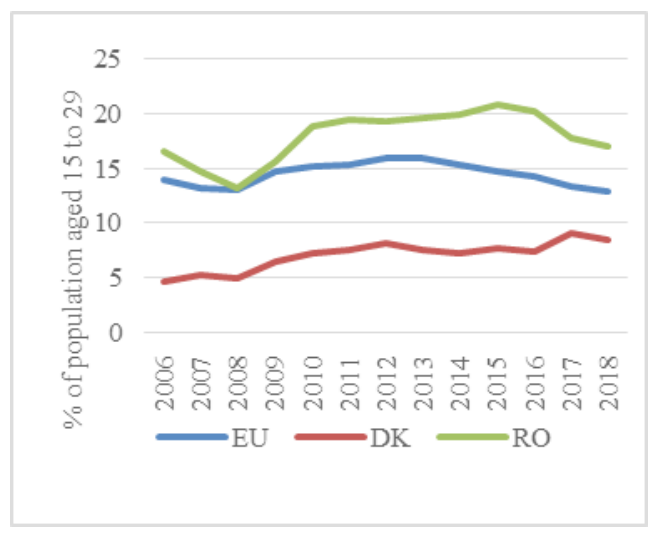

Source: Eurostat

Gender equality and women empowerment, a subject where Romania is overcoming the counterparts, it was also highlighted previously that on average women earn more than men, but the monthly income can't be compared to Denmark which is around 6 times higher. Notably is also the case signaled in the Danish National Review where efforts are made to eliminate violence.

\section{GOAL 6: Clean Water and Sanitation}

The position presented in Figure 6 is, unfortunately, the representation of rural Romania and the consequence of poor provincial management, situation mostly caused by political instability. While Denmark has more than $88 \%$ of the population connected to wastewater treatment, Romania still struggles to secure for $50 \%$ of its population the basic wastewater connection. Situation that needs urgent act, even though in 2017 connections increased by $136 \%$ over 2009 .

Figure 6. Population connected to at least secondary wastewater treatment (SDG6)

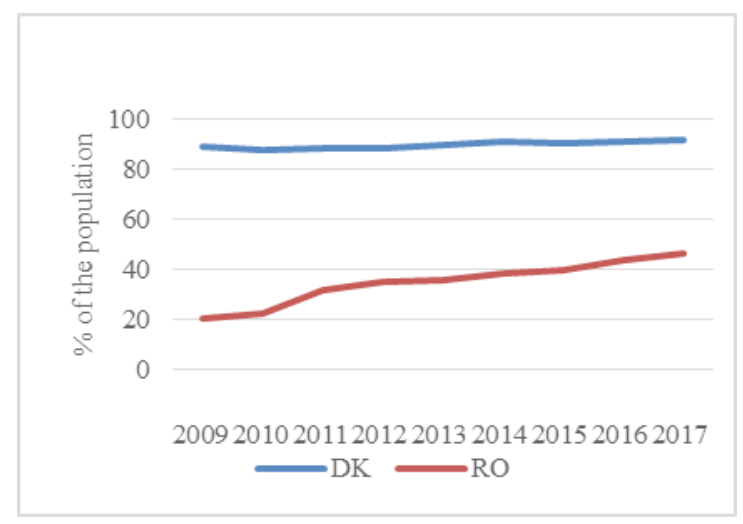

Source: Eurostat 
The illustration at Figure 7 is again representing rural Romania, where a significant part of the population is unable to meet their heating necessities. The decreasing trend over the years is signaling good conditions for Romania while Denmark recorded a small increase over the last years. In Romania, the lowest percentage was recorded in 2018 with around $10 \%$ of the population being unable to maintain their homes adequately warm, while Denmark recorded its lowest in 2010 with $1.5 \%$ of the population. Will be an impressive improvement for Romania if the EU average could be overtaken.

Figure 7. Population unable to keep home adequately warm (SDG6)

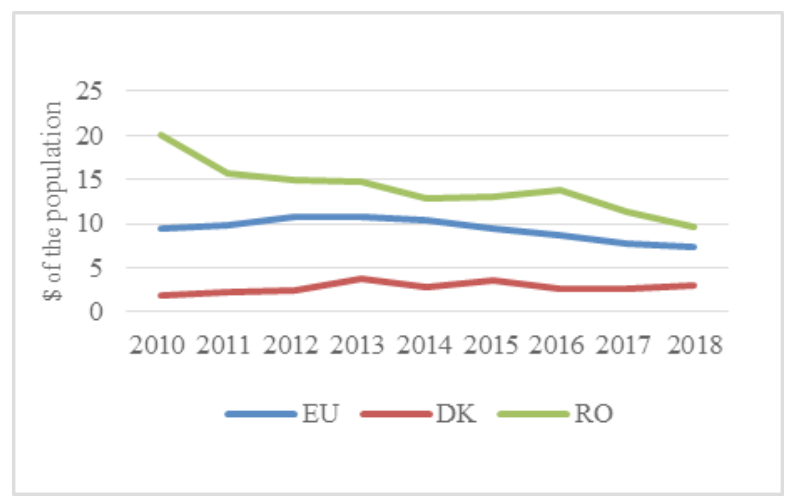

Source: Eurostat

While Denmark clearly overcame this aspect in entirety, Romania still struggles to supply its population with fresh water and sanitation access. The numbers have grown in the last couple of years but still, a continuous effort should be made to allow the entirety of the population to have access to essential services.

\section{GOAL 7: Affordable and Clean Energy}

The seventh goal relates to modern and reliable energy supply for everyone, Romania is clearly recording some issue in this aspect, whilst Denmark is increasingly focusing on clean energy and managed to frame a clear investment plan for sustainable energy. What should be highlighted is that Romania, a country with such significant resource possibility should not rely that much from energy imports and could frame a multiple organizational layer plan to frame a resource-energetical-efficient plan focused on sustainability and local resources abundance.

GOAL 8: Decent Work and Economic Growth

As shown in Figure 8, Denmark's GDP per capita overtakes with a significant margin both the EU average and the Romanian one. The variance for Romania recorded in 2018 a 55\% increase over 2006, while for Denmark and the EU, recorded only a 3\% and respectively a $11 \%$ increase. The ascending trend is good for all countries, but the large gap between Romania and the EU average should diminish. 
Figure 8. Real GDP per capita (SDG8)

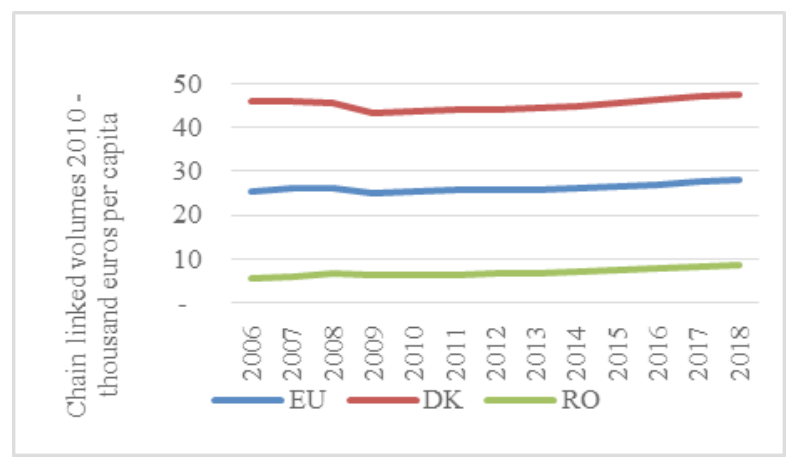

Source: Eurostat

The inclusive and economic prosperity together with great work conditions lack guidance in Romania's Voluntary Review, but it could be improved with the economic growth registered in the last couple of years and what is great to be pointed is that, percentual, Romania is investing more and more yearly, an excellent method of improvement.

\section{GOAL 9: Industry, Innovation and Infrastructure}

As it can be noticed in Figure 9, Romania is not focusing enough on the R\&D, an important factor for improvement and growth in a adding value sector. On the opposite pole, Denmark recognizes the importance of $R \& D$ and surpasses the EU average. Romania is not spending enough, below $1 \%$ of the GDP, the highest value being recorded in 2017 with $0.4 \%$ of GDP spent on R\&D.

Figure 9. Gross domestic expenditure on R\&D (SDG9)

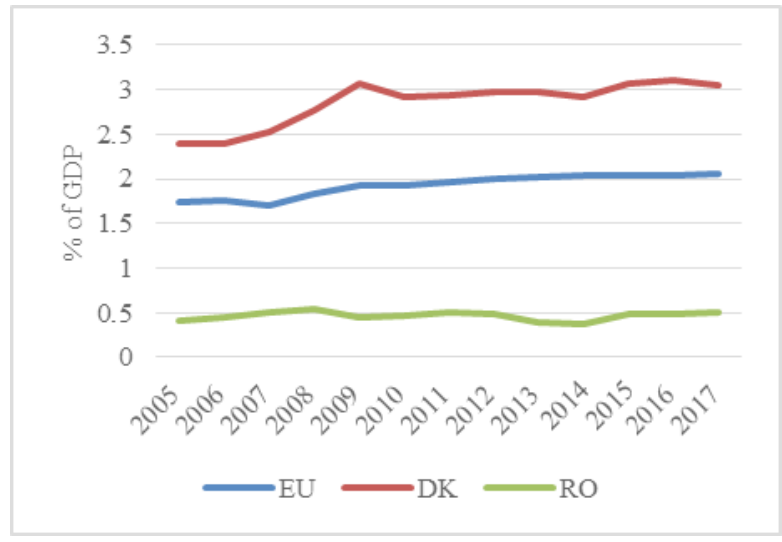

Source: Eurostat

This goal translates for countries like Denmark, into clear volumetric measurements of the passengers' numbers and the small and medium enterprises labor force. Transportation and motorways are a weak point of Romania and together with a lack of political involvement, it can't be easily reinforced. The EU database focuses on 
industries like R\&D, high-end technology manufacturing and public transportation where innovation should drastically improve the quality of the services delivered, sectors that need realignment with the western society, especially for Romanians.

\section{GOAL 10: Reduced Inequality}

Tenth goal focuses on inequalities reduction among nations, where Denmark focuses on household expenditure and general incomes, Romania showed political instability and room for improvement. Inequality can be notified even within the EU borders where most of the imports and exports happen within the EU customs but do not extend to outside developing areas. Importing from developing counties helps the local community and promotes growth to the respective economical actors.

\section{GOAL 11: Sustainable Cities and Communities}

The interesting rate shown in Figure 10 is representing a fair view of the recycling rate in Romania, this aspect of a circular and sustainable economy has not had the chance to develop yet, leaving room for improvement. On the opposite pole, there sits Denmark with a rate that matches the EU average, showing the incredible efforts of the municipalities to recycle. It is good to note the Romanian variance over the years and the visible improvement but only a 14\% recycling rate in 2017 is not meeting the EU standards and it should represent an urgent matter for all the stakeholders.

Figure 10. Recycling rate of municipal waste (SDG9)

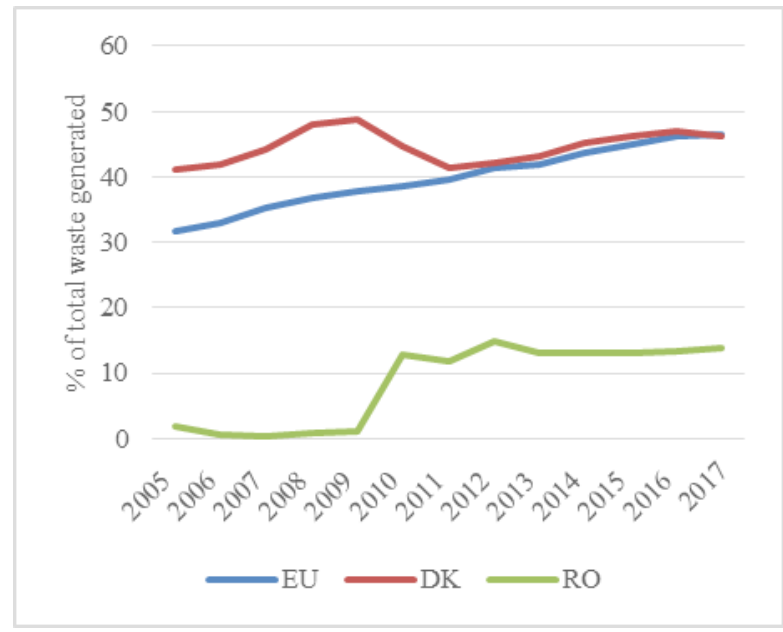

Source: Eurostat

In the National Reviews, Romania showed the decreasing of poor people over the last couple of years where Denmark showed the investment into the urban air, culture and environment in the same report section. What was previously noted is that Romania needs to take Denmark as an example and to encourage the corporate sector to invest more into the environmental protection and not to rely only on the governmental efforts in order to have a clean air to breathe. In a crowded world, it is very relevant to show 
the area where a person or family successfully carries out their day-to-day activities and it could be observed that Romanians lack many square meters when compared to the EU average. Cities, represented by the citizens, together with the municipalities, private and public sector should focus more on achieving the recycling quotas imposed by the EU Environmental Agency of 50\% for the household materials by 2020 through the Waste Framework Directive.

\section{GOAL 12: Responsible Consumption and Production}

The next SDG, relies on sustainable consumptions patterns, both countries framing relevant lines but Denmark is one step ahead of other nations especially of Romania when it is measuring its own efforts with unique indices. This aspect can be translated into a growth in production sector especially where the respective country bears sustainable resources.

\section{GOAL 13: Climate Action}

Goal thirteen focuses on urgent actions taken to counter the climate changes, it was shown before that both analyzed countries did not publish any data in the voluntary review in this category. Romania should consider the international commitment for climate change and with a greener focus of the governmental bodies, could take real action in order to retaliate the climate emergency status declared by the EU officialities.

\section{GOAL 14: Life Below Water}

The fourteenth goal in Denmark focuses on the fish catch that should always be preserved under sustainable levels while Romania is not highlighting enough about this SDG, even though fishing is having a real importance for the coastal counties of Romania. Romania should describe more of its efforts under the Operational Programme for Fishing and Maritime Businesses.

\section{GOAL 15: Life on Land}

The fifteenth goal stands for actions against desertification and features sustainable forest management. Denmark points the efforts in this regard and the importance of anti-desertification measures while Romania is presenting the rich landscape of the forests and not a significant action against the massive deforestation that left scars for the present and future generations. Big efforts should be considered for Romania to restore the original forest area and to rapidly increase the forest area.

\section{GOAL 16: Peace and Justice Strong Institutions}

The sixteenth SDG promotes justice, peace and inclusiveness. Romania is not showing suggestive data in the voluntary papers while Denmark is open to help the international detainees but where Romania is lacking initiative is in the homicide death rate where major investigations should be realized. The judicial system of Romania could be more independent and should absolutely be out of political influences, situation related in the last couple of years for Romania and together with the general corruption status could represent a key focus of every governance. 


\section{GOAL 17: Partnerships to achieve the Goal}

The seventeenth SDG targets the global partnership and both countries focus on international cooperation. Governmental debt could represent a diminishable objective for all the EU member states in order to regain more economical independency on the one hand, but on the other hand, taxes needs to charge more its citizens (both individuals and legal entities) for the negative environmental impact in order to encourage positive attitude towards the environment.

\section{Conclusion}

Romania as previously observed, has the potential to improve its sustainable development path and the respective goals, if a proper investment strategy is applied. Denmark is for sure an example, not only for Romania but for all the EU Member States.

The SDG-s brought new clarity towards the overall strategy and defined the universal and interconnected layers of their applicability. It is essential to understand that success can only be achieved through cooperation, clear funding schemes and effort recognition even at individual level.

Romanian policies and practices need to consider the multiple signs and international trends as the ones highlighted in the present paper (extensive public and private growth mechanisms) in order to outline the most up-to-date priorities for the country. Statistical background and strong reporting capabilities indicate a data-collective national system of Romania, that points out pluses and minuses in this SDG-s achievement journey. To formulate the clear commitment of the government, even though it is already backed up by legal frameworks, it could be noted how the authorities would deliver satisfactory results not only through standardized yearly reports. Romania, a country that triples the population of Denmark but is hardly achieving one fifth of the Danish GDP in euro/capita, is having room for improvement. Socioeconomic disparities, potential maximization, innovation \& research focus, cooperation promotion, public health state, education improvement, young people unemployment, waste management, responsible consumption, climate action and international cooperation represent urgent needs .

Essential to acknowledge that policies, especially global frameworks as the SDG-S, can't be applied uniformly at large scale, they are implemented according to the national, regional and local peculiarities as Denmark proceeds even from the first chapter of the National Review.

\section{Paper limits}

All data analyzed above and structured as multiple suggestions for Romania may represent a starting point for reaching all the SDG-s; nevertheless, one should remember that these suggestions are based on the official data and documents available at the current date. The main objective of this paper has been reached but there is still plenty of data that needs to be analyzed for further alignment with the Agenda 2030 goals. 
The strategies presented above are strictly tied to the analyzed database and should be considered as being theoretical because it is needed a more complex study that perfectly tailors national needs as a part of a well-defined action plan. The datasets used in the regression models do not reach present time, 2020, but match the Voluntary National Reviews time span.

\section{Further studies}

Could the SDG-s be within our reach by 2030? How could progress be marked if not by replicating the efforts and results of the top performing States across the globe? The progress of the least SDG achieving countries could represent, together with a more in-depth plan for each state, the objective of future studies.

Other nations' approach that are situated in the top of the SDG index could also represent an interesting and different point of view then the one of Denmark. Romania's progress beyond year 2020 and what changes would be recorded during the next Voluntary Review cycle is also a possible subject of interest.

\section{Conflict of interests}

The author declares no conflict of interest.

\section{References}

1. Cruceanu, D., Anghel, M. G., \& Diaconu, A. (2016). Multiple liniar regression utilized in variables correlation analysis. Romanian Statistical Review(10), 110113 [in Romanian: Regresia multipla liniara utilizata in analiza corelatiei dintre variabile].

2. Education Ministry. (2020, February 15). Retrieved from Baccalaureate Statistics: http://static.bacalaureat.edu.ro/2020/

3. Eurostat. (2020, March 3). Retrieved from Farm Labour Force: https://ec.europa. eu/eurostat/databrowser/view/tag00020/default/table?lang=en

4. Eurostat. (2020, April 12). Retrieved from Economic accounts for agriculture - agricultural income: https://ec.europa.eu/eurostat/web/products-datasets/ product?code=aact_eaa06

5. Eurostat. (2020, March 12). Retrieved from Length of motorways and e-roads: https:// appsso.eurostat.ec.europa.eu/nui/show.do?dataset=road_if_motorwa\&lang=en

6. Eurostat. (2020, January 20). Retrieved from People at risk of poverty or social exclusion by age and sex: https://appsso.eurostat.ec.europa.eu/nui/show. do?dataset=ilc_peps01\&lang=en

7. Eurostat. (2020, April 3). Retrieved from Agricultural holdings by agricultural area: https://ec.europa.eu/eurostat/databrowser/view/tag00001/default/table?lang=en

8. Eurostat. (2020, March 6). Retrieved from Expenditure on education as \% of GDP or public expenditure: https://appsso.eurostat.ec.europa.eu/nui/show. do?dataset=educ_figdp\&lang=en 
9. Eurostat. (2020, February 18). Retrieved from Structure of earnings survey 2014: https://ec.europa.eu/eurostat/cache/metadata/en/earn_ses2014_esms.htm

10. Eurostat. (2020, April 13). Retrieved from Supply, transformation and consumption of renewables and wastes: https://appsso.eurostat.ec.europa.eu/nui/show. do?dataset $=$ nrg_cb_rw\&lang=en

11. Eurostat. (2020, February 7). Retrieved from National expenditure on environmental protection by institutional sector: https://appsso.eurostat.ec.europa.eu/nui/ submitViewTableAction.do

12. Eurostat. (2020, January 17). EU Open Data Portal. Retrieved from Special Eurobarometer 449: Gender-based violence: https://ata.europa.eu/euodp/en/data/ dataset/S2115_85_3_449_ENG

13. Eurostat. (2020, Febrary 13). Gross domestic product at market prices. Retrieved from https:/ec.europa.eu/eurostat/databrowser/view/tec00001/default/table?lang=en

14. F.A.O. (2020, February 11). Faostat. Retrieved from Macro Indicators: http://www. fao.org/faostat/en/\#data/MK

15. Glass, L.-M., \& Newig, J. (2019). Governance for achieving the Sustainable Development Goals: How important are participation, policy coherence, reflexivity, adaptation and democratic institutions? Earth System Governance, 2.

16. INSSE, R. N. (2020, March 12). Retrieved from Romanian Statistical Yearbook: https://insse.ro/cms/sites/default/files/field/publicatii/anuarul_statistic_al_ romaniei_carte_ro.pdf

17. Ministry of Environment. (2019, September 15). Romania's Voluntary National Review: Transformation Towards a Sustainable and Resilient Romania. Retrieved September 11, 2019, from https://sustainabledevelopment.un.org/content/ documents/19952Voluntary_National_Review_ROMANIA_with_Cover.pdf

18. Ministry of Finance. (2019, October 6). Report for the Voluntary National Review: Denmark's Implementation of the 2030 Agenda for Sustainable Develpment. Retrieved September 7, 2019, from https://sustainabledevelopment.un.org/content/ documents/16013Denmark.pdf

19. PricewaterhouseCoopers. (2017). Principles for Responsible Investment, The SDG Investment Case. Retrieved March 11, 2020, from https://www.unpri.org/ download?ac $=5909$

20. Sachs, J., Shmidt-Traub, G., Kroll, C., Lafortune, G., \& Fuller, G. (2019). Sustainable Development Report 2019. New York: Bertelsmann Stiftung and Sustainable Development Solutions Network (SDSN).

21. U.N. (2015). The Millenium Development Goals Report. New York: United Nations.

22. U.N. (2020, August 5). Sustainable Develpment Goals. Retrieved from https:// www.undp.org/content/undp/en/home/sustainable-development-goals.html

23. World Bank. (2020, April 25). Retrieved from World Bank Data: https://data. worldbank.org/indicator/NY.GDP.MKTP.KD.ZG?locations=RO

24. World Bank. (2020, April 15). UNESCO Institute for Statistics. Retrieved from Literacy rate, adult total (\% of people ages 15 and above) - Romania: https:/data. worldbank.org/indicator/SE.ADT.LITR.ZS?locations $=$ RO 


\section{ANNEX}

Table A1. Dual analysis of the SDG-s based on the National Voluntary Reviews

\begin{tabular}{|c|c|c|c|}
\hline ڤ & Denmark - status & Romania - status & Romania - suggestions \& remarks \\
\hline 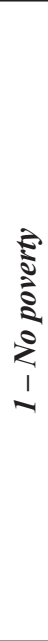 & $\begin{array}{l}\text { Danes have noted } \\
\text { the absence of a } \\
\text { national poverty } \\
\text { threshold as } \\
\text { indicated by UN } \\
\text { and several indices } \\
\text { are presented to } \\
\text { describe the risk of } \\
\text { poverty. }\end{array}$ & $\begin{array}{l}\text { Romania is not focusing } \\
\text { specifically around this } \\
\text { SDG. }\end{array}$ & $\begin{array}{l}\text { Because Romania did not include this goal in } \\
\text { the paper review does not mean that poverty is } \\
\text { eliminated. According to Eurostat, the GDP at } \\
\text { current market prices by NUTS } 2 \text { in Romania, } \\
\text { showed an ascending trendline from } 2008 \text { to } \\
2017 \text { and recorded the maximum value, in its } \\
\text { least developed region, around EUR } 6800 \text { per } \\
\text { capita in 2017, compared to the least developed } \\
\text { region in Denmark (GDP wise), Sjaelland } \\
\text { which recorded a value of EUR } 34800 \text { per } \\
\text { capita in } 2017 \text { (Eurostat, 2020). Romania's } \\
\text { NE Region still sits behind weak economic } \\
\text { background. Macroeconomic decisions } \\
\text { are not important to be noted but at least, } \\
\text { Romanian review should highlight the measures } \\
\text { implemented in the least developed regions in } \\
\text { order to increase the quality of life. }\end{array}$ \\
\hline 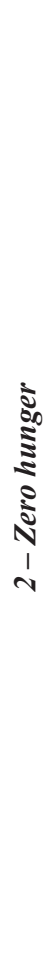 & $\begin{array}{l}\text { Denmark calculated } \\
\text { several indices } \\
\text { analyzing volume } \\
\text { of production per } \\
\text { labor unit and the } \\
\text { agricultural surface } \\
\text { of sustainable } \\
\text { agriculture. }\end{array}$ & $\begin{array}{l}\text { Romania is not focusing } \\
\text { specifically around this } \\
\text { SDG. }\end{array}$ & $\begin{array}{l}\text { An important aspect that should be highlighted } \\
\text { under Romania's review is the share of } \\
\text { Romanian farmers in the total number of } \\
\text { European farmers, they accounted around } \\
21.4 \% \text { of total EU farmers in 2009-2018 period } \\
\text { (Eurostat, 2020). Moreover, Romanian farmers } \\
\text { have the lowest income levels in the EU; this } \\
\text { should stimulate the public authorities to pay } \\
\text { more attention to this very important work area } \\
\text { (Eurostat, 2020). } \\
\text { When making the comparison between Danish } \\
\text { and Romanian agricultural output, the } \\
\text { values recorded for Denmark in } 2014 \text { were } \\
\text { approximatively USD 13.4 mil (with a } 12 \% \\
\text { increase reported from 2008) and for Romania } \\
\text { in 2014 were approximatively USD } 18.6 \text { mil, } \\
\text { with a 30\% decrease reported from } 2008 \\
\text { (F.A.O., 2020). } \\
\text { Denmark has a higher gross agricultural } \\
\text { output per capita (USD 2379) than Romania } \\
\text { (USD 931). In this case, Romanian authorities } \\
\text { and businesses should consider new ways } \\
\text { of improving agricultural output and to give } \\
\text { more opportunities to the small farmers, } 92.2 \\
\% \text { of the holdings had less than } 5 \text { ha in } 2017 \\
\text { (Eurostat, 2020). }\end{array}$ \\
\hline
\end{tabular}




\begin{tabular}{|c|c|c|c|}
\hline ถ & Denmark - status & Romania - status & Romania - suggestions \& remarks \\
\hline 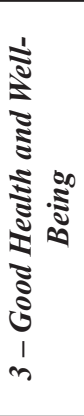 & $\begin{array}{l}\text { Denmark is also } \\
\text { tackling multiple } \\
\text { targets and creating } \\
\text { special indices } \\
\text { adapting the UN } \\
\text { goals to the Danish } \\
\text { specificity. }\end{array}$ & $\begin{array}{l}\text { Romania is following } \\
\text { the National Health } \\
\text { Strategy and is targeting } \\
\text { different parts of this } \\
\text { SDG with the maternal } \\
\text { mortality analysis, } \\
\text { under five mortality } \\
\text { topics, trendline of } \\
\text { AIDS and other, in } \\
\text { total } 8 \text { out of the } 9 \text { total } \\
\text { target goals. }\end{array}$ & $\begin{array}{l}\text { Romania, in this case, can improve the better } \\
\text { tracking of most affective illnesses and to work } \\
\text { for an improved health system. }\end{array}$ \\
\hline 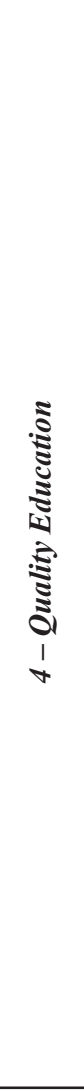 & $\begin{array}{l}\text { The indicators } \\
\text { of this SDG are } \\
\text { focusing on the } \\
\text { quality of education } \\
\text { and the quality } \\
\text { of learning and } \\
\text { assuring that all } \\
\text { children have a } \\
\text { minimum proficiency } \\
\text { in language-reading } \\
\text { and mathematics. } \\
\text { Another topic of the } \\
\text { Education SDG is } \\
\text { the information and } \\
\text { communications } \\
\text { technology skills } \\
\text { recognized as a } \\
\text { current trend for the } \\
\text { success of becoming } \\
\text { an entrepreneur in } \\
\text { order to effectively } \\
\text { join the labor } \\
\text { market. Danish } \\
\text { government } \\
\text { emphasizes the } \\
\text { average of digital } \\
\text { skills above the } \\
\text { EU level for all the } \\
\text { pupils. }\end{array}$ & $\begin{array}{l}\text { A design based on each } \\
\text { target is absent, but } \\
\text { the current structure is } \\
\text { focusing on Romania's } \\
\text { most important, } \\
\text { education-related, } \\
\text { problems that are early } \\
\text { school leavers and } \\
\text { teachers'salaries. }\end{array}$ & $\begin{array}{l}\text { An important factor is the literacy rate, } \\
\text { Denmark did not need to mention due to the } \\
\text { complete fulfillment for the whole population, } \\
\text { but Romania should have mentioned details } \\
\text { about this indicator as in } 2015 \text { (World Bank, } \\
\text { 2020) it recorded around } 98.75 \% \text { of the } \\
\text { population older than 14. Another important } \\
\text { aspect that Romania should be following is } \\
\text { the principle of obtaining results and it should } \\
\text { consider the proportion of students promoting } \\
\text { the baccalaureate examination, 69.7\% in } \\
2018 \text { according to the Education Ministry } \\
\text { of Romania (Education Ministry, 2020) and } \\
\text { the general improvement of it as this exam } \\
\text { represents an important milestone for each } \\
\text { student's future. What is quintessential to be } \\
\text { improved in Romania is the GDP allocated to } \\
\text { education, in } 2014 \text { it recorded the lowest value } \\
\text { from the whole EU with } 2.75 \% \text { compared to the } \\
\text { Denmark's } 7.6 \% \text { which represents the largest } \\
\text { percentage of GDP allocation for education } \\
\text { (Eurostat, 2020). }\end{array}$ \\
\hline
\end{tabular}




\begin{tabular}{|c|c|c|c|}
\hline ڤ & Denmark - status & Romania - status & Romania - suggestions \& remarks \\
\hline 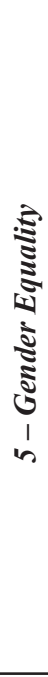 & $\begin{array}{l}\text { Denmark focuses on } \\
\text { violence elimination, } \\
\text { seats held by } \\
\text { women in national } \\
\text { governmental } \\
\text { bodies and women } \\
\text { access to high end } \\
\text { technology. }\end{array}$ & $\begin{array}{l}\text { Romania is not focusing } \\
\text { specifically around this } \\
\text { SDG. }\end{array}$ & $\begin{array}{l}\text { When analyzing the earnings survey, it can be } \\
\text { noticed that Romanians monthly salary in the } \\
\text { Services type of industry in } 2014 \text { was EUR } 546 \\
\text { for men while for women was EUR 551, the } \\
\text { only sector where the women overpass the men, } \\
\text { while in Denmark, data for women recorded } \\
\text { EUR } 2953 \text { against EUR } 4098 \text { for men as it } \\
\text { could be observed even in this type of industry, } \\
\text { men overtake the monthly earnings of women } \\
\text { (Eurostat, 2020). In Romania a good thing is } \\
\text { that there are no big differences between men } \\
\text { and women in most of the categories, but the } \\
\text { actual level of the income is way below the } \\
\text { average of the EU. } \\
\text { Romania should maintain the small gap but } \\
\text { to find better ways for improving the monthly } \\
\text { income in the upcoming future as it is needed } \\
\text { for a prosperous and sustainable life. }\end{array}$ \\
\hline 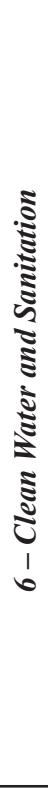 & $\begin{array}{l}\text { In Denmark, the } \\
\text { focus is on adequate } \\
\text { water supply, water } \\
\text { quality, wastewater } \\
\text { treatment and } \\
\text { freshwater } \\
\text { withdrawal. } 100 \% \\
\text { of the Danish people } \\
\text { have access to } \\
\text { water, sanitation } \\
\text { and sewage. }\end{array}$ & $\begin{array}{l}\text { This SDG is formulated } \\
\text { under the Protocol for } \\
\text { Water together with } \\
\text { the one for Health. It } \\
\text { consists in detailing } \\
\text { past infrastructure } \\
\text { projects that developed } \\
\text { the water and } \\
\text { wastewater networks } \\
\text { together with treatment } \\
\text { plants and the work } \\
\text { done to improve the } \\
\text { flood protection system. }\end{array}$ & $\begin{array}{l}\text { It is interesting to note that Romanian water } \\
\text { supply access throughout the country covers } \\
\text { only } 62.4 \% \text { of the total need (only } 62.4 \% \text { of the } \\
\text { population in } 2014 \text { had access to the public } \\
\text { water supply system) and what should be } \\
\text { highlighted is the fact that Romania's drinking } \\
\text { water supply network remained unchanged } \\
\text { for the period } 2012-2017 \text { when counting } \\
\text { the localities (out of the } 3284 \text { communes, } \\
\text { towns and cities only } 2534 \text { were connected } \\
\text { to the drinking water supply installations) } \\
\text { (INSSE, 2020). Another topic that needs to be } \\
\text { mentioned is that only } 52 \% \text { of the population } \\
\text { was connected to the sewage system at the end } \\
\text { of } 2018 \text { and under } 10 \% \text { of the rural citizens } \\
\text { benefit of these kind of services according to the } \\
\text { paper's protocol on achieving the Water SDG } \\
\text { and the government is continuously working } \\
\text { to develop the infrastructure, but greater effort } \\
\text { is needed due to the high importance of this } \\
\text { service for the wellbeing of the nation. }\end{array}$ \\
\hline
\end{tabular}




\begin{tabular}{|c|c|c|c|}
\hline ร & Denmark - status & Romania - status & Romania - suggestions \& remarks \\
\hline 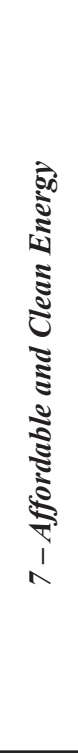 & $\begin{array}{l}\text { Denmark is } \\
\text { targeting several } \\
\text { indices and among } \\
\text { them it can be } \\
\text { found, population's } \\
\text { access to electricity, } \\
\text { population relying } \\
\text { on clean energy } \\
\text { and technology, } \\
\text { share of renewable } \\
\text { energy out of total } \\
\text { energy consumption } \\
\text { and investments } \\
\text { in clean energy as } \\
\text { percentage of GDP, } \\
\text { index measuring } \\
\text { close to } 3.6 \% \text { in } \\
2015 .\end{array}$ & $\begin{array}{l}\text { The report focuses } \\
\text { on the renewable } \\
\text { energy share and on } \\
\text { the future change of } \\
\text { biomass to renewable } \\
\text { energy for household } \\
\text { heating. Recognizing } \\
\text { the high percentage of } \\
\text { firewood used in the } \\
\text { rural areas, multiple } \\
\text { plans for alternative } \\
\text { heading sources are } \\
\text { being developed. In } \\
\text { order to fulfill this SDG, } \\
\text { Romania is designing } \\
\text { several lines of action } \\
\text { for a plan in some } \\
\text { industries formulating } \\
\text { energy cost efficiency } \\
\text { procedures. }\end{array}$ & $\begin{array}{l}\text { Romania is willing to highlight the constant } \\
\text { effort that should be recalled but in fact, no } \\
\text { indices are presented. Romanian government } \\
\text { should follow the Danish example or at least } \\
\text { use the European Commission's indices, } \\
\text { the most important of them are the share } \\
\text { of renewable energy in gross final energy } \\
\text { consumption (Denmark recorded a } 124 \% \\
\text { increase in } 2017 \text { compared to } 2005 \text { reaching } \\
\text { almost } 36 \% \text { for the Renewable energy source; } \\
\text { a } 1446 \% \text { increase in } 2017 \text { compared to } 2005 \text {, } \\
\text { almost } 6.9 \% \text { in the transport sector and a } 104 \% \\
\text { increase in } 2017 \text { compared to } 2005 \text { reaching } \\
\text { almost } 46.6 \% \text { in the heating and cooling sector } \\
\text { while Romania recorded only a } 42 \% \text { growth for } \\
\text { the first category, 298\% growth for the second } \\
\text { category and } 48 \% \text { growth in the third category) } \\
\text { (Eurostat, 2020). }\end{array}$ \\
\hline 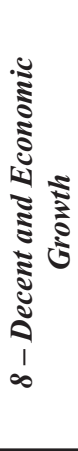 & $\begin{array}{c}\text { Denmark's } \\
\text { current review } \\
\text { is highlighting } \\
\text { the GDP growth } \\
\text { compared to the rest } \\
\text { of the EU, material } \\
\text { consumption, female } \\
\text { earnings, pay gaps } \\
\text { and unemployment } \\
\text { rate. }\end{array}$ & $\begin{array}{c}\text { Romania is not focusing } \\
\text { specifically around this } \\
\text { SDG. }\end{array}$ & $\begin{array}{l}\text { What should be highlighted, and Romania } \\
\text { could mention is the GDP annual growth rate } \\
\text { that it recorded historical heights (6.9\% in } \\
2017 \text { compared to } 4 \% \text { in 2015) as compared } \\
\text { to Denmark (2.2\% in } 2017 \text { compared to } 2 \% \\
\text { in 2015) (World Bank, 2020). What is also } \\
\text { relevant for Romania is the low unemployment } \\
\text { rate standing at an average of } 4 \% \text { in } 2018 \\
\text { across all educational levels compared to the } \\
5.3 \% \text { of Denmark under the same conditions. } \\
\text { For both countries, the unemployment rate fell } \\
\text { down year on year. }\end{array}$ \\
\hline 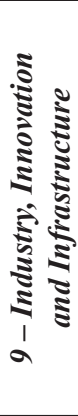 & $\begin{array}{l}\text { Denmark is } \\
\text { reviewing the } \\
\text { passenger and } \\
\text { freight volumes, } \\
\text { manufactures added } \\
\text { value, persons } \\
\text { employed in small } \\
\text { scale enterprises } \\
\text { and several other } \\
\text { indices for all the } 5 \\
\text { targets of this } S D G \text {. }\end{array}$ & $\begin{array}{l}\text { Romania is not focusing } \\
\text { around this } S D G .\end{array}$ & $\begin{array}{l}\text { Romania should be highlighting the strategies } \\
\text { for infrastructure development but what is } \\
\text { important to note is the fact that Romania's } \\
\text { motorways length was summing } 763 \mathrm{~km} \text { in } 2017 \\
\text { while in Denmark the total length was of } 1308 \\
\text { km, comparing the E-road length in Romania of } \\
6200 \mathrm{~km} \text { to the } 945 \mathrm{~km} \text { of Denmark (Eurostat, } \\
2020 \text { ). Addressing to the total area of the } \\
\text { country, Romania is not satisfying the need of } \\
\text { motorways. Infrastructure represents an urgent } \\
\text { issue for the Romanian governance. }\end{array}$ \\
\hline
\end{tabular}




\begin{tabular}{|c|c|c|c|}
\hline ڤ & Denmark - status & Romania - status & Romania - suggestions \& remarks \\
\hline 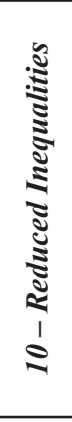 & $\begin{array}{l}\text { Topic focusing } \\
\text { on household } \\
\text { expenditure and } \\
\text { incomes. }\end{array}$ & $\begin{array}{l}\text { Romania is not focusing } \\
\text { around this SDG. }\end{array}$ & $\begin{array}{l}\text { Both nations should consult this specific SDG } \\
\text { targets and create better policies to ensure } \\
\text { equal opportunities, knowing the political } \\
\text { instability of the recent Romanian times, } \\
\text { the governance could improve their actions. } \\
\text { What is important to be noted is that in } 2018 \text {, } \\
\text { population at risk of poverty or social exclusion } \\
\text { in Romania recorded } 6360 \text { thousand people } \\
\text { (33\% from the total population) while Denmark } \\
\text { had only } 997 \text { thousand people (17\% from the } \\
\text { total population) (Eurostat, 2020). }\end{array}$ \\
\hline 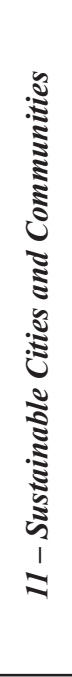 & $\begin{array}{l}\text { Danish paper } \\
\text { sticks closely } \\
\text { to most of the } \\
\text { targets, analyzing } \\
\text { the ratio of land } \\
\text { consumption rate to } \\
\text { population growth } \\
\text { rate, expenditure on } \\
\text { cultural and natural } \\
\text { conservation, } \\
\text { environment impact } \\
\text { in cities and air } \\
\text { quality. }\end{array}$ & $\begin{array}{l}\text { Focusing on the } \\
\text { Smart Cities concept, } \\
\text { analyzing the people } \\
\text { living in poor } \\
\text { conditions (emphasizing } \\
\text { the general yearly } \\
\text { decrease), noise } \\
\text { pollution, urban air } \\
\text { pollution and the SDG } \\
\text { targets completion } \\
\text { status. }\end{array}$ & $\begin{array}{l}\text { What needs to be highlighted is the Romania's } \\
\text { representation in the national expenditure on } \\
\text { environment protection index database from } \\
\text { Eurostat, a measurement that involves the total } \\
\text { EU economy that does not contain Romania } \\
\text { at all. Denmark is leading the charts when } \\
\text { compared to the size of the country, spending } \\
\text { EUR } 5876 \text { million in } 2016 \text { for this important } \\
\text { aspect and the least significant part of the } \\
\text { total economy is the governmental sector } \\
\text { that is easily overtaken by households and } \\
\text { corporations (for the corporate sector, the } \\
\text { environmental protection expenditure triples the } \\
\text { governmental one in 2016) (Eurostat, 2020). } \\
\text { What Romania could do is to keep the track of } \\
\text { the private and governmental environmental } \\
\text { protection expenditure and continuously try to } \\
\text { improve it. }\end{array}$ \\
\hline 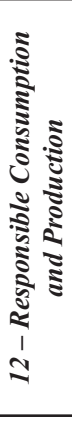 & $\begin{array}{c}\text { Denmark is focusing } \\
\text { on multiple targets } \\
\text { composing its own } \\
\text { indices as material } \\
\text { consumption, } \\
\text { hazardous waste } \\
\text { and recycling rate. }\end{array}$ & $\begin{array}{l}\text { Romania highlights the } \\
\text { importance of a strong } \\
\text { national framework } \\
\text { for sustainable } \\
\text { consumption and } \\
\text { production analyzing } \\
\text { waste generators, } \\
\text { resource productivity } \\
\text { and most of the policies } \\
\text { put in place for the } \\
\text { future. }\end{array}$ & $\begin{array}{l}\text { The policies described for Romania are a } \\
\text { good start, but sustainable consumption and } \\
\text { production is a next level improvement that } \\
\text { should be focused on by the authorities in direct } \\
\text { cooperation with the industries and the NGOs. }\end{array}$ \\
\hline 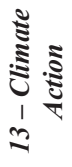 & $\begin{array}{l}\text { Denmark is not } \\
\text { presenting any data } \\
\text { at the current stage. }\end{array}$ & $\begin{array}{l}\text { Romania is not focusing } \\
\text { specifically around this } \\
\text { SDG. }\end{array}$ & $\begin{array}{c}\text { Both countries lack data and analysis in this } \\
\text { regard signaling the urgent need of a concrete } \\
\text { plan that needs to be implemented for global } \\
\text { climate aid. }\end{array}$ \\
\hline
\end{tabular}




\begin{tabular}{|c|c|c|c|}
\hline \% & Denmark - status & Romania - status & Romania - suggestions \& remarks \\
\hline 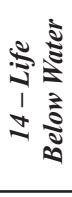 & $\begin{array}{c}\text { Denmark focuses } \\
\text { on maintaining fish } \\
\text { stock percentage } \\
\text { within sustainable } \\
\text { levels. }\end{array}$ & $\begin{array}{l}\text { Romania is not focusing } \\
\text { specifically around this } \\
\text { SDG. }\end{array}$ & $\begin{array}{c}\text { Romania should consider real indices in } \\
\text { order to preserve its rich maritime and water } \\
\text { ecosystems. }\end{array}$ \\
\hline 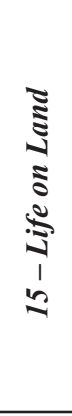 & $\begin{array}{c}\text { Denmark is } \\
\text { highlighting the } \\
\text { slightly larger } \\
\text { forested area in this } \\
\text { section. }\end{array}$ & $\begin{array}{l}\text { Chapter focusing on } \\
\text { the rich biodiversity } \\
\text { of Romania, on } \\
\text { the surfaces of the } \\
\text { protected areas and } \\
\text { their management, } \\
\text { ecosystem, species } \\
\text { and genetic diversity, } \\
\text { conservation status and } \\
\text { the continuous work for } \\
\text { Romanian forests. }\end{array}$ & $\begin{array}{l}\text { Romania, besides all the indices, could think } \\
\text { and implement a real strategy in order to } \\
\text { preserve the rich natural landscape and its } \\
\text { wonders, combat the deforestation and increase } \\
\text { the governmental and private expenditure } \\
\text { dedicated to nature conservation. }\end{array}$ \\
\hline 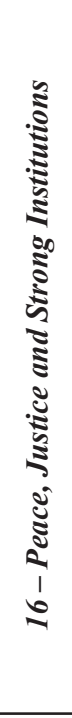 & $\begin{array}{l}\text { Denmark is } \\
\text { highlighting } \\
\text { the victims of } \\
\text { international } \\
\text { homicide and } \\
\text { unsentenced } \\
\text { detainees. }\end{array}$ & $\begin{array}{l}\text { Romania is not focusing } \\
\text { specifically around this } \\
\text { SDG. }\end{array}$ & $\begin{array}{l}\text { Romania should present a true and fair } \\
\text { representation of the current state of the } \\
\text { violence. According to the Eurobarometer } 449 \text {, } \\
\text { in Romania } 36 \% \text { of the respondents answering } \\
\text { "how common is the domestic violence against } \\
\text { women" say that it is "very common" and } 48 \% \\
\text { say that is "fairly common" while in Denmark } \\
9 \% \text { are saying that it is "very common" and } \\
50 \% \text { are saying that it is "fairly common" (out } \\
\text { of the } 27818 \text { respondents - study concluded } \\
\text { in 2016) (Eurostat, 2020). Another important } \\
\text { topic is that of the domestic violence being a } \\
\text { matter of family and should be treated in the } \\
\text { family, Romania being the second country } \\
\text { in EU having } 32 \% \text { of the same respondents } \\
\text { "totally agreeing" with this fact while in } \\
\text { Denmark only } 6 \% \text { of the same people "totally } \\
\text { agree", Denmark being the last second country } \\
\text { in EU totally agreeing this subject. }\end{array}$ \\
\hline 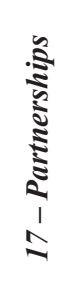 & $\begin{array}{l}\text { Denmark is focusing } \\
\text { on the same targets } \\
\text { presenting the latest } \\
\quad \text { figures. }\end{array}$ & $\begin{array}{c}\text { Targeting specific } \\
\text { indicators including } \\
\text { the involvement in } \\
\text { humanitarian projects, } \\
\text { bilateral funds, global } \\
\text { partnership and } \\
\text { inter-institutional } \\
\text { cooperation. }\end{array}$ & $\begin{array}{c}\text { Romania should continue its international focus } \\
\text { and could also insert and track the relevant } \\
\text { indices. }\end{array}$ \\
\hline
\end{tabular}

Source: (Ministry of Environment, 2019), (Ministry of Finance, 2019) and other sources mentioned in the text: Eurostat, FAO, The World Bank, European Commission, Romanian Ministry of Education, Romanian Statistical Yearbook for 2018 and The Romanian National Institute of Statistics 
Table A2. SDG Bullets - matrix of the analyzed Indices

\begin{tabular}{|c|c|c|c|c|c|c|c|c|c|}
\hline$\underline{\mathrm{SDG}}$ & GDP & 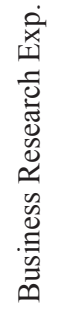 & 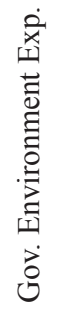 & 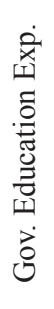 & 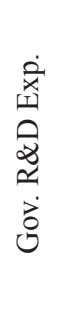 & 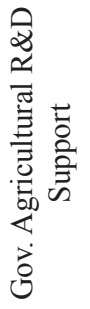 & 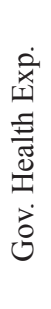 & 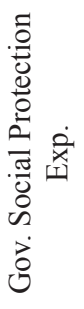 & 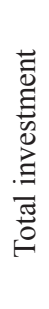 \\
\hline 1. No poverty & $\theta$ & & & & & & & & \\
\hline 2. Zero hunger & 8 & & & & & 0 & & & \\
\hline $\begin{array}{l}\text { 3. Good Health and Well- } \\
\text { Being }\end{array}$ & & & $\theta$ & & & & $\theta$ & & $\theta$ \\
\hline 4. Quality Education & $\theta$ & $\theta$ & & $\theta$ & & & & & $\theta$ \\
\hline 5. Gender Equality & & & & $\theta$ & & & & 0 & $\theta$ \\
\hline \multicolumn{10}{|l|}{ 6. Clean Water and Sanitation } \\
\hline $\begin{array}{c}\text { 7. Affordable and Clean } \\
\text { Energy }\end{array}$ & $\theta$ & $\theta$ & & & & $\theta$ & & & \\
\hline $\begin{array}{l}\text { 8. Decent and Economic } \\
\text { Growth }\end{array}$ & 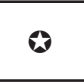 & & $\theta$ & $\theta$ & $\theta$ & $\theta$ & & & $\theta$ \\
\hline $\begin{array}{l}\text { 9. Industry, Innovation and } \\
\text { Infrastructure }\end{array}$ & & $\theta$ & $\mathbf{0}$ & $\theta$ & 0 & 0 & & & \\
\hline 10. Reduced Inequalities & $\theta$ & & & & $\theta$ & & $\theta$ & $\theta$ & \\
\hline $\begin{array}{l}\text { 11. Sustainable Cities and } \\
\text { Communities }\end{array}$ & & $\theta$ & $\theta$ & & $\theta$ & $\theta$ & & & \\
\hline $\begin{array}{l}\text { 12. Responsible Consumption } \\
\text { and Production }\end{array}$ & & $\theta$ & 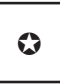 & & $\theta$ & 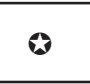 & & & \\
\hline 13. Climate Action & & & $\theta$ & & & & & & \\
\hline 14. Life Below Water & & & $\theta$ & & & & & & \\
\hline \multicolumn{10}{|l|}{ 15. Life on Land } \\
\hline $\begin{array}{l}\text { 16. Peace, Justice and Strong } \\
\text { Institutions }\end{array}$ & & & & & & & $\theta$ & $\theta$ & \\
\hline 17. Partnerships & & & & & & & $\theta$ & $\theta$ & \\
\hline
\end{tabular}

Source: Author's correlation

Table A3. Database - Denmark

\begin{tabular}{|c|c|c|c|c|c|c|c|c|c|}
\hline $\begin{array}{c}\text { UM: Euro/ } \\
\text { Capita }\end{array}$ & GDP & $\begin{array}{c}\text { Business } \\
\text { Research } \\
\text { Exp. }\end{array}$ & $\begin{array}{l}\text { Gov. } \\
\text { Environment } \\
\text { Exp. }\end{array}$ & $\begin{array}{l}\text { Gov. } \\
\text { Education } \\
\text { Exp. }\end{array}$ & $\begin{array}{l}\text { Gov. } \\
\text { R\&D } \\
\text { Exp. }\end{array}$ & $\begin{array}{c}\text { Gov. } \\
\text { Agricultural } \\
\text { R\&D Support }\end{array}$ & $\begin{array}{l}\text { Gov. } \\
\text { Health } \\
\text { Exp. }\end{array}$ & $\begin{array}{l}\text { Gov. Social } \\
\text { Protection } \\
\text { Exp. }\end{array}$ & $\begin{array}{c}\text { Total } \\
\text { investment }\end{array}$ \\
\hline 2000 & 42,190 & 616 & 211 & 3,411 & 118 & 78 & 2,827 & 9,408 & 9,075 \\
\hline 2001 & 42,390 & 674 & 254 & 3,483 & 114 & 78 & 2,925 & 9,623 & 9,029 \\
\hline 2002 & 42,430 & 717 & 297 & 3,485 & 76 & 79 & 3,013 & 9,759 & 8,758 \\
\hline 2003 & 42,490 & 739 & 255 & 3,451 & 76 & 79 & 3,017 & 10,070 & 8,795 \\
\hline 2004 & 43,520 & 718 & 261 & 3,572 & 74 & 83 & 3,133 & 10,184 & 8,991 \\
\hline 2005 & 44,400 & 724 & 266 & 3,590 & 67 & 94 & 3,241 & 10,079 & 9,399 \\
\hline 2006 & 45,990 & 740 & 276 & 3,555 & 74 & 91 & 3,357 & 9,980 & 10,702 \\
\hline 2007 & 46,210 & 813 & 231 & 3,519 & 37 & 75 & 3,558 & 9,935 & 10,864 \\
\hline
\end{tabular}


Economics of Agriculture, Year 67, No. 4, 2020, (pp. 1309-1336), Belgrade

\begin{tabular}{|c|c|c|c|c|c|c|c|c|c|}
\hline $\begin{array}{c}\begin{array}{c}\text { UM: Euro/ } \\
\text { Capita }\end{array} \\
\text { Indicator => DK } \\
\text { Year }\end{array}$ & GDP & $\begin{array}{c}\text { Business } \\
\text { Research } \\
\text { Exp. }\end{array}$ & $\begin{array}{l}\text { Gov. } \\
\text { Environment } \\
\text { Exp. }\end{array}$ & $\begin{array}{c}\text { Gov. } \\
\text { Education } \\
\text { Exp. }\end{array}$ & $\begin{array}{l}\text { Gov. } \\
\text { R\&D } \\
\text { Exp. }\end{array}$ & $\begin{array}{c}\text { Gov. } \\
\text { Agricultural } \\
\text { R\&D Support }\end{array}$ & $\begin{array}{l}\text { Gov. } \\
\text { Health } \\
\text { Exp. }\end{array}$ & $\begin{array}{l}\text { Gov. Social } \\
\text { Protection } \\
\text { Exp. }\end{array}$ & $\begin{array}{c}\text { Total } \\
\text { investment }\end{array}$ \\
\hline 2008 & 45,700 & 887 & 229 & 3,417 & 32 & 74 & 3,610 & 9,871 & 10,484 \\
\hline 2009 & 43,220 & 921 & 173 & 3,652 & 26 & 73 & 3,847 & 10,502 & 8,717 \\
\hline 2010 & 43,840 & 859 & 175 & 3,753 & 26 & 80 & 3,770 & 10,872 & 7,939 \\
\hline 2011 & 44,240 & 867 & 177 & 3,754 & 27 & 69 & 3,716 & 10,927 & 8,034 \\
\hline 2012 & 44,170 & 861 & 177 & 3,197 & 31 & 92 & 3,843 & 10,866 & 8,295 \\
\hline 2013 & 44,410 & 835 & 222 & 3,772 & 31 & 69 & 3,775 & 10,880 & 8,460 \\
\hline 2014 & 44,890 & 835 & 224 & 3,427 & 31 & 93 & 3,861 & 10,774 & 8,601 \\
\hline 2015 & 45,630 & 885 & 183 & 3,554 & 32 & 97 & 3,879 & 10,723 & 9,058 \\
\hline 2016 & 46,720 & 939 & 187 & 3,688 & 33 & 77 & 3,924 & 10,699 & 9,821 \\
\hline 2017 & 47,360 & 933 & 189 & 3,731 & 43 & 87 & 3,978 & 10,609 & 10,036 \\
\hline 2018 & 48,260 & 941 & 193 & 3,795 & 43 & 99 & 4,006 & 10,569 & 10,632 \\
\hline
\end{tabular}

Source: Eurostat

Table A4. Database - Romania

\begin{tabular}{|c|c|c|c|c|c|c|c|c|c|}
\hline $\begin{array}{c}\text { UM: } \\
\text { Euro/ } \\
\text { Capita }\end{array}$ & $\hat{\imath}$ & 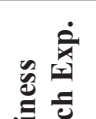 & $\dot{\vec{E}} \stackrel{\vec{E}}{\dot{E}}$ & 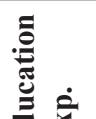 & 离 & 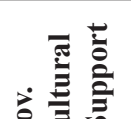 & 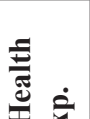 & 畜 & 玉 \\
\hline$\frac{\underline{\text { Indicator }}}{\frac{\text { RO }}{\text { Year }}}$ & $\overrightarrow{0}$ & 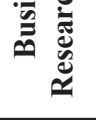 & 已. & 可 & $\begin{array}{l}\approx \\
\dot{0}\end{array}$ & ن & 它 & 递 & e \\
\hline 2000 & 4,010 & 10 & 8 & 114 & 3 & 0.3 & 168 & 417 & 767 \\
\hline 2001 & 4,130 & 10 & 12 & 134 & 5 & 0.3 & 169 & 442 & 869 \\
\hline 2002 & 4,250 & 10 & 9 & 149 & 4 & 0.3 & 174 & 429 & 912 \\
\hline 2003 & 4,370 & 10 & 9 & 150 & 6 & 0.3 & 153 & 424 & 994 \\
\hline 2004 & 4,860 & 11 & 5 & 158 & 6 & 0.3 & 156 & 481 & 1,084 \\
\hline 2005 & 5,120 & 11 & 15 & 177 & 7 & 0.3 & 169 & 517 & 1,196 \\
\hline 2006 & 5,560 & 12 & 22 & 237 & 8 & 1.4 & 183 & 556 & 1,480 \\
\hline 2007 & 6,050 & 13 & 24 & 249 & 10 & 1.4 & 218 & 605 & 2,138 \\
\hline 2008 & 6,730 & 11 & 34 & 277 & 15 & 2.4 & 242 & 740 & 2,510 \\
\hline 2009 & 6,410 & 12 & 38 & 259 & 10 & 1.4 & 256 & 840 & 1,667 \\
\hline 2010 & 6,190 & 11 & 50 & 216 & 11 & 2.9 & 260 & 860 & 1,615 \\
\hline 2011 & 6,350 & 11 & 57 & 194 & 13 & 1.9 & 267 & 826 & 1,729 \\
\hline 2012 & 6,510 & 12 & 52 & 192 & 13 & 1.5 & 247 & 807 & 1,786 \\
\hline 2013 & 6,760 & 8 & 54 & 207 & 13 & 0.7 & 270 & 777 & 1,674 \\
\hline 2014 & 7,020 & 11 & 56 & 219 & 11 & 0.8 & 281 & 800 & 1,705 \\
\hline 2015 & 7,320 & 15 & 73 & 227 & 14 & 1.2 & 307 & 834 & 1,813 \\
\hline 2016 & 7,720 & 21 & 46 & 257 & 12 & 1.2 & 309 & 888 & 1,766 \\
\hline 2017 & 8,320 & 24 & 42 & 276 & 13 & 1.1 & 358 & 973 & 1,865 \\
\hline 2018 & 8,740 & 26 & 70 & 289 & 13 & 0.7 & 411 & 1,014 & 1,833 \\
\hline
\end{tabular}

Source: Eurostat 